\title{
MEMPERKUAT NALAR TEOLOGI ISLAM MODERAT DALAM MENYIKAPI PANDEMI COVID-19 DI PIMPINAN RANTING PEMUDA MUHAMMADIYAH BANDAR PULAU PEKAN
}

\author{
Nurman Ginting1 ${ }^{1}$ Riyan Pradesyah², Amini $^{3}$, Hadi Saputra Panggabean ${ }^{4}$ \\ 1Fakultas Agama Islam Universitas Muhammadiyah Sumatera Utara \\ 2 Fakultas Agama Islam Universitas Muhammadiyah Sumatera Utara \\ 3Fakultas Keguruan dan Ilmu Pendidikan Universitas Muhammadiyah Sumatera Utara \\ 4Fakultas Agama Islam dan Humaniora Universitas Panca Budi \\ suryapijar@yahoo.com
}

\begin{abstract}
Religion, for some people, is a guideline for determining the direction to be directed in their life. In life in this world, the most important thing is peace of mind and body in society. In keeping up with the current changes, a sound reasoning process is urgently needed to address this to break the chain of the spread of the Covid-19 outbreak. Moderate Islam is a teaching that can keep up with the times and does not abandon the teachings afterward. Moderate Islam is a religion that can balance the movement of changes in life in society. The understanding of average Islamic values is currently being eroded by the changing times. Many young people tend to be pragmatic, exclusive, and intolerant in responding to the situation and conditions of the Covid-19 pandemic, which is spreading so rapidly today.
\end{abstract}

Keywords: Theological Reason, Moderate Islam, Responding, the Covid-19 Pandemic, Muhammadiyah Youth

\begin{abstract}
Abstrak
Agama bagi sebagian masyarakat di dunia adalah pedoman untuk menentukan arah yang harus dituju dalam hidupnya. Dalam kehidupan di dunia ini, hal yang paling penting adalah sebuah kedamaian jiwa dan raga dalam bermasyarakat. Dalam mengimbangi perubahan-perubahan yang terjadi saat ini, maka proses penalaran yang baik sangat dibutuhkan sebagai salahsatu solusi menyikapi hal tersebut untuk memutus mata rantai penyebaran wabah Covid-19. Islam moderat adalah ajaran yang mampu mengikuti perkembangan jaman dan tidak meninggalkan ajaran-ajaran sesudahnya. Sehingga Islam Moderat merupakan agama yang mampu mengimbangi pergerakan perubahan dalam kehidupan di dalam masyarakat. Pemahaman nilai-nilai Islam moderat saat ini mulai tergerus oleh perubahan zaman, sehingga banyak pemuda-pemudi yang cenderung bertidak pragmatis, eksklusif dan intoleran dalam menyikapi situasi dan kondisi pandemic Covid-19 yang merebak begitu pesat saat ini.
\end{abstract}

Kata kunci: Nalar Teologis, Islam Moderat, Menyikapi, Pandemi Covid-19, Pemuda Muhammadiyah 
Nurman Ginting, dkk. Memperkuat Nalar Teologi Islam Moderat Dalam Menyikapi ...

\section{PENDAHULUAN}

Pandemi Covid-19 telah melanda dunia dan mengguncang segala aspek kehidupan manusia di manca negara, dan Indonesia menjadi salahsatu diantara negara yang terdampak dari wabah Covid-19 tersebut. Dampak yang sangat luar bisa disebabkan oleh virus tersebut, sehingga mengubah peradaban sekaligus tatanan kehidupan manusia modern dan menjadi bencana berskala global. Pandemi ini juga banyak menimbulkan korban, tidak hanya nyawa manusia saja yang terinfeksi, melainkan banyak juga sektor kehidupan lainnya terganggu.

Pandemic Covid-19 telah melahirkan dunia baru, yang merubah kebiasaan umat manusia. Hal itu, juga berdampak pada pemahaman keagamaan yang fatalistis hingga free will. Kehadiran Covid-19 mendorong umat manusia secara terpaksa untuk meninjau ulang cara beragama di tengah pandemi teresebut. Peninjau tersebut sudah barang tentu harus memperhatikan banyak hal, dengan logika penalaran yang kontruktif melalui pendekatan teologi Islam (Haedar, 2010). Kaidah-kaidah agama menjadi pedoman dalam menyikapi peristiwa pandemic Covid-19 yang bersumber dari Al-Qur'an, Hadist maupun Ijma' para ulama (Tahir,2020).

Pandangan agama terkait dengan wabah Covid-19 mulai diperbincangkan banyak kalangan. Pandangan agama menjadi solusi sentral untuk memberikan pemahaman yang komprehensif bagi umat manusia agar tidak gegabah dalam menghadapi pandemic Covid-19. Karena dampaknya yang begitu totalitas bagi sebahagian tatanan kehidupan manusia, termasuk terkait persoalan kegiatan keagamaan. Dalam menjawab segala bentuk permasalahan yang muncul yang diakibatkan oleh pandemi Covid-19, sangat dibutuhkan peran nalar sebagai bentuk pengoptimalisasian informasi yang tersirat dalam pesanan agama yang bersumber pada Al-Qur'an dan Hadist. (Syatar, 2020)

Dalam Islam wabah pandemi Covid-19 yang melanda saat ini merupakan bentuk dari takdir Allah Swt dan akan berlaku bagi siapapun baik itu dia manusia yang tergolong beriman atau kufur, baik atau buruk, jelak atau tampan, tua atau muda jika tidak mentaati aturan protokoler kesehatan. Diperlukan sebuah nalar keagamaan untuk dapat menelaah keadaan tersebut. Nalar yang Islam bangun dalam menyikapi Kesehatan yaitu berpaut kepada Allah Swt berdasarkan petunjuk-petunjuk agama yang bersumber pada Al-Qur'an dan Sunnah.

Kesempurnaan ajaran Islam sebagai agama Rahmatan lil alamin harus menjadi pijakan dasar bagi umat Islam untuk mengedepankan nilai-nilai ajarannya dalam menyikapi keadaan seperti saat sekarang ini. Pandemi Covid-19 tidak dapat dianggap sebagai isu-isu yang syarat akan kepentingan para penguasa yang ada di dunia ini. Sebagai orang beriman, umat Islam harus tunduk dengan apa yang telah di syariatkan Allah Swt agar tidak menjadikannya sebagai sebuah ritualitas semata. Karena Islam itu Rahmatan Lil Alamin yang menghimpun segala solusi kehidupan duniawi dan ukhrawi (Najib, 2012). Nalar yang Islam bangun dalam menyikapi pandemi Covid-19, dianjurkan untuk menghindari, menjauhi segala bentuk yang dapat membawa kepada ke mudharatan.

Dalam Islam dikenal istilah Maqashid al-Syari'ah, yaitu tujuan suatu hukum dalam Islam ditetapkan. Nalar Teologi Islam bersandarkan pada Maqashid al-Syari'ah sebagai sebuah solusi dalam menyikapi pandemi 
Covid-19 yang merabak saat ini dan segala perubahan yang terjadi yang diakibatkan dari penyebarannya. Dalam Maqashid al-Syari'ah salahsatu kaidahnya adalah nafs (nyawa). Setiap sesuatu yang mengancam eksistensi nyawa seseorang maka, dianjurkan untuk menghindarinya (Zuhdi, 2014). Bentuk ikhtiar yang harus dipedomani umat Islam dalam menyikapi pandemi Covid-19, yaitu menghindari wabah tersebut dengan tetap mengikuti syariat Allah Swt.

Memperkuat nalar teologi Islam moderat dalam menyikapi pandemi Covid-19 sebagai upaya untuk memutus mata rantai penyebaran pandemi Covid19. Dalam hal tersebut peran pemuda sebagai agent of change sangat strategis dalam ikut serta memutus mata rantai penyebaran pandemi covid-19. Perlunya penegasan penalaran dalam konteks agama bagi pemuda dalam menyikapi pandemi Covid-19 agar tidak salah menyikapi kondisi tersebut. Apalagi saat ini, banyak isu dan informasi yang beredar diberbagai media sosial, yang menegasi bahwa pandemi Covid-19 bukannya suatu keadaan yang harus dikhawatirkan karena, itu merupakan tipu-muslihat dan persaingan bisnis dan politik luar negeri, yang sengaja diciptakan untuk meraup keuntungan secara financial. (Kevin D, 2009)

Melihat keadaan tersebut, maka berbagai elemen masyarakat, khususnya organisasi sosial Islam dalam konteks ini adalah Muhammadiyah dan ortomortomnya termasuk Pemuda Muahmmadiyah, dituntut untuk hadir dalam rangka melakukan penguatan nalar teologis Islam Moderat dalam menyikapi pandemi Covid-19 tersebut. Pemuda Muhammadiyah dan Nasyiatul Aisyiyah sebagai organisasi yang besar dengan sistem ideologi moderat yang dimiliki, diharapkan dapat menggulirkan paham yang bercorak tengahan (moderat). Posisi Pemuda Muahmmadiyah dalam konteks ini cukup strategis, tidak saja karena memiliki anggota yang cukup besar, organisasi ini juga memiliki sistem ideologi yang terkandung dalam berbagai teks resmi Muhammadiyah. Dalam teks tersebut terkandung berbagai paham keislaman yang bercorak wasathiyyah (Qorib, 2018). Hal tersebut, yang harus dipahami Pemuda Muhammadiyah dalam menyikapi pandemi Covid-19.

PRPM Bandar Pulau Pekan, dalam hal ini merupakan salahsatu bagian yang memiliki peran dalam mewujudkan tujuan dari Islam Moderat untuk menyikapi pandemi Covid-19 berdasarkan nalar teologi keagamaan. Keberadaan organisasi Otonom angkatan muda Muhammadiyah ini, sangat strategis untuk dilakukan penguatan terhadap nalar teologis Islam Moderat, dengan harapan dapat berpikir, bertindak, dan bersikap sesuai dengan nilai-nilai Islam moderat dan berdasarkan nilai-nilai yang terkandung pada teks-teks ideologi Muhammadiyah dalam menyikapi pandemi Covid-19. Maka dari itu, perlunya kegiatan ini untuk dilakukan, dalam rangka penguatan pemahaman nalar teologi Islam moderat dalam menyikapi pandemi Covid-19 di Pimpinan Ranting Pemuda Muhammadiyah Bandar Pulau Pekan.

\section{Permasalahan Mitra}

Kurangnya pemahaman pemuda dalam menetukan sikap, ketika dihadapkan dengan merebaknya pandemi Covid-19 yang disandarkan pada nilai-nilai agama. Sehingga menyebabkan sikap acuh-tak acuh yang berujung pada pemikiran dan tindakan yang pragmatis. Hal inilah yang melatar belakangi perubahan orientasi nilai dan sikap dalam bermuhammadiyah, 
Nurman Ginting, dkk. Memperkuat Nalar Teologi Islam Moderat Dalam Menyikapi ...

sehingga memerlukan penguatan nalar teologi Islam moderat, yang nantinya akan memperkuat pemahaman pemuda muhammadiyah, dalam menentukan sikap dalam mengahadapi pandemic Covid-19. Dari penjelasan tersebut, maka dapat disimpulkan permasalahan mitra sebagai berikut :

1) Kurangnya pemahaman dalam menyikapi situasi pandemic Covid19 atau kondisi yang disandarkan pada nilai-nilai agama

2) Pola pikir yang eksklusif dalam menyikapi pandemi Covid-19

3) Perubahan-perubahan alam pikiran yang cenderung Pragmatis, materialistis, dalam menyikapi berbagai perubahan yang diakibatkan pandemi Covid-19.

4) Perubahan orientasi nilai dan sikap dalam bermuhammadiyah karena berbagai factor (inernal dan eksternal) yang memerlukan standar nilai dan norma yang jelas dari Muhammadiyah sendiri untuk menyikapi pandemi Covid-19.

\section{METODE PELAKSANAAN}

Program

Pengembangan

Kemitraan (PKPM) ini dalam pelaksanaannya menggunakan berberapa tahapan dan metode pelaksanaan sebagai berikut:

\section{Pelatihan}

Pelatihan PKPM penguatan nalar teologi Islam moderat, dikalangan pemuda PRPM Bandar Pulau Pekan. Pelatihan tersebut akan dilakukan kepada pemuda yang terhimpun dalam organisasi pimpinan ranting pemuda Muhammadiyah Bandar Pulau Pekan. Pelatihan yang akan dilakukan meliputi 3 hal, adapun hal-hal tersebut adalah sebagai berikut :

1) Penguatan teks-teks ideologis Muhammadiayah dalam menyikapi pandemi Covid-19
2) Melakukan penguatan nalar teologis Islam moderat dalam upaya menyikapi pandemi Covid19.

3) Penguatan sikap moderasi meliputi tawazun (seimbang), tawasuth (penengah), tasamuh (toleran) dalam menyikapi pandemi Covid19

\section{Pendampingan}

Pendampingan yang dilakukan dalam kegiatan penguatan nalar teologi Islam moderat dilaksanakan Selama 1 Bulan, dimana pelatihan dibutuhkan selama 8 kali pertemuan, sedangkan implementasi serta refleksi dan tindak lanjut dibutuhkan masing-masing 2 kali pertemuan. Setiap pertemuan akan memenghabiskan waktu sekitar 4-5 jam. Kegiatan PKPM akan dilaksanakan di Aula Kantor Kepala Desa Bandar Pulau Pekan, Kabupaten Asahan.

\section{Tahapan Kegiatan}

Untuk mendukung terealisasinya solusi yang ditawarkan, maka ada beberapa prosedur yang harus dilakukan yaitu:

1) Tahap Persiapan

Setelah proposal ini dinyatakan lolos oleh LP2M UMSU tim akan menyusun beberapa tahapan sebagai berikut:

a. Melakukan koordinasi dengan Pimpinan Ranting Pemuda Muhammadiyah Bandar Pulau Pekan

b. Merancang jadwal pelaksanaan kegiatan yang terintegrasi antara kesiapan tim dengan waktu yang dimiliki para peserta pelatihan.

2) Tahap Pelaksanaan

Pelaksanaan Program Kemitraan Pengembangan Muhammadiyah dalam hal Memperkuat Nalar Teologi Islam Moderat dalam Menyikapi Pandemi Covid-19 di Pimpinan Ranting Pemuda 
Muhammadiyah Bandar Pulau Pekan, sebagai berikut :

a. Melakukan sosialisasi kepada Pemuda di Pimpinan Ranting Pemuda Muhammadiyah Bandar Pulau Pekan.

b. Menyampaikan hasil pemetaan dan potensi untuk memperkuat nalar teologi dalam menyikapi pandemi Covid-19 di Pimpinan Ranting Pemuda Muhammadiyah Bandar Pulau Pekan.

c. Melakukan pelatihan penguatan nalar teologi Islam moderat dalam menyikapi pandemi Covid-19, di kalangan pemuda di Pimpinan Ranting Pemuda Muhammadiyah Bandar Pulau Pekan.

3) Tahap Evaluasi

$$
\text { Pada tahap akhir seluruh }
$$
kegiatan, akan dilakukan evaluasi terhadap program-program yang telah diterapkan dalam PKPM ini, evaluasi tersebut menyangkut apakah peserta sudah sudah memahami tentang penguatan nalar teologi Islam moderat dalam menyikapi pandemi Covid-19 di Pimpinan Ranting Pemuda Muhammadiyah Bandar Pulau Pekan.

\section{Partisipasi Mitra}

Mitra dalam program PKPM ini adalah Pimpinan Ranting Pemuda Muhammadiyah Bandar Pulau Pekan. Partisipasi mitra akan sangat berpengaruh dalam pencapaian tujuan kegiatan ini mengingat mitra berperan aktif dalam perekrutan peserta yang akan diberikan pelatihan penguatan nalar teologi Islam moderat dalam menyikapi pandemi Covid-19. Selain itu, partisipasi lain dari kedua mitra tersebut adalah:

a. Melakukan pendampingan kepada peserta selama program ini berlangsung

b. Memonitor pencapaian yang didapat oleh peserta dari penguatan nalar teologi Islam Moderat dalam menyikapi pandemi Covid-19.

Melakukan program tindak lanjut setelah program ini berlangsung dengan mendampingi peserta pada saat praktek dalam memahami penguatan nalar teologi Islam Moderat dalam menyikapi pandemi Covid-19.

\section{HASIL DAN PEMBAHASAN}

Capaian Program Kemitraan Pengembangan Muhammadiyah terkait Memperkuat Nalar Teologi Islam Moderat Dalam Menyikapi Pandemi Covid-19 di Pimpinan Ranting Pemuda Muhammadiyah Bandar Pulau Pekan, adalah sebagai berikut:

\section{Kegiatan Survey Awal}

Survei awal yang dilakukan sebelum kegiatan ini disahkan oleh LPPM UMSU. Kemudian setelah proposal PKPM ini dinyatakan lulus dan didanai oleh UMSU, tim pelaksanan kegiatan melakukan kordinasi Kembali dengan pihak mitra yang pada waktu sebelum sudah menyetujui untuk bekerjasama dalam kegiatan atau program yang dimaksud. Adapun kordinasi yang dilakukan setelah proposal PKPM ini dinyatakan lulus dan didanai, yaitu, Pertama, tim PKPM melakukan kordinasi dengan mitra yang dalam hal ini adalah Pimpinan Ranting Pemuda Muhammadiyah Bandar Pulau Pekan. Agenda pada pertemuan tersebut adalah membicarakan terkait hal teknis yang meliputi: tempat pelaksanaan kegiatan PKPM, jumlah peserta yang akan terlibat dalam kegiatan tersebut, kemudian fasilistas lainnya yang mendukung kegiatan atau programa tersebut. Dalam pertemuan tersebut tim juga menyampaikan gambaran rangkaian acara yang akan dilaksanakan pada tanggal 7 Juni 2020. Selain itu 
Nurman Ginting, dkk. Memperkuat Nalar Teologi Islam Moderat Dalam Menyikapi ...

juga, tim menyampaikan terkait dengan materi kegiatan akan disampaikan kepada peserta kegiatan, yaitu mengenai Nalar Toleogi Islam Moderat Dalam Menyikapi Pandemi Covid-19 di Pimpinan Ranting Pemuda Muhammadiyah Bandar Pulau Pekan. Hal tersebut tim sampaikan kepada mitra untuk menyamakan persepsi terkait dengan pentingnya kegiatan tersebut dilakukan bagi para pemuda, terkhusus pemuda yang terhimpun dalam Pimpinan Ranting Pemuda Muhammadiyah Bandar Pulau Pekan.

Kedua, melakukan konfimasi dan kordinasi dengan Pimpinan Cabang Pemuda Muhammadiyah Bandar Pulau dan Pimpinan Ranting Muhammadiyah Bandar Pulau Pekan. Hal tersebut tim lakukan agar dapat bersinergi dengan pimpinan ortom tersebut untuk dapat mensukseskan kegiatan PKPM yang akan diselenggarakan di Desa Bandar Pulau Pekan. Pada pertemuan tersebut tim juga menyampaikan maksud dan tujuan dilaksanakannya kegiatan PKPM sebagai wujud dari pelaksanaan Catur Dharma Perguruan Tinggi, yaitu melakukan pengabdian kepada masyarakat terkait dengan pengembangan kemuhammadiyahan. Dalam kesempatan itu tim juga menyampaikan agenda acara serta materi yang akan disampaikan pada peserta.

\section{KegiatanPersiapan Pelaksanaan PKPM}

Setelah tim PKPM melakukan konfirmasi dan kordinasi dengan pihak yang menjadi mitra dalam kegiatan ini, maka, pada tahap selanjutnya tim PKPM melakukan persiapan secara teknis maupun non-teknis. Adapun persiapan yang dilakukan adalah, Pertama, melakukan studi Pustaka terkait dengan program memperkuat nalar teologi Islam moderat dalam menyikapi pandemic covid-19 bagi pemuda yang terhimpun dalam ortom Muhammadiyah. Kedua, menentukan dan menetapkan strategi dan metode yang digunakan pada saat pelaksanaan program sehingga nantinya PKPM yang dilaksanakan berjalan dengan efektif dan materi juga tersampaikan secara maksimal. Ketiga, mempersiapkan bahan dan alat yang menjadi prasarana yang dapat digunakan dalam kegiatan PKPM.

\section{Kegiatan Pelaksanaan}

Pelaksanaan Program Kemitraan Pengembangan Muhammadiyah dengan judul Memperkuat Nalar Teologi Islam Moderat dalam Menyikapi Pandemi Covid-19 di Pimpinan Ranting Pemuda Muhammadiyah Bandar Pulau Pekan dilaksanakan pada tanggal 7 Juni 2020. Adapun lokasi kegiatan beralamat di Desa Bandar Pulau Pekan Kecamatan Bandar Pulau, Kabupaten Asahan, dan Adapun tempat dilaksanakannya kegiatan PKPM bertempat di aula Kantor Kepala Desa Bandar Pulau Pekan. Waktu pelaksanaan kegiatan berlangsung mulai pukul 19.00 wib s/d selesai. Jumlah peserta yang mengikuti kegiatan tersebut berjumlah 20 peserta yang terdiri dari kader Pemuda Muhammadiyah di Pimpinan Ranting Pemuda Muhammadiyah Bandar Pulau Pekan. Acara kegiatan PKPM tersebut dibuka oleh Ketua Pimpinan Ranting Pemuda Muhammadiyah Bandar Pulau Pekan saudara Amri Simanjuntak.

Dalam sambutannya saudara Amri Simanjuntak selaku Ketua Pimpinan Ranting Pemuda Muhammadiyah Bandar Pulau Pekan sangat mengapresiasi atas pelaksanaan pelatihan tersebut, apalagi tema yang diusung oleh tim PKPM UMSU sangat berkaitan dengan peran pemuda dalam menyikapi kondisi yang sedang dihadapi saat ini yaitu penyebaran 
pademi covid-19 yang melanda hampir diseluruh belahan dunia terkhusus di Indonesia. Fenomena yang diakibatkan oleh Pandemi covid-19 harus disadari oleh pemuda saat ini, bahwa dampak dari covid-19 telah melemahkan berbagai aktivitas kehidupan manusia, baik itu dari segi ekonomi, pendidikan, dan lain sebagainya. Tapi, walaupun seperti itu kenyataannya kita tidak perlu khawatir dan cemas, karena penyebaran pandemi covid-19 tersebut dapat diantisipasi dengan tetap patuh terhadap protokoler Kesehatan yang telah ditetapkan pemerintah. Maka, dari itu peran pemuda sangat strategis untuk ikut serta menyuarakan pentingnya melaksanakan protokoler Kesehatan dalam ruang public untuk memutus mata-rantai penyebaran pandemi covid19 tersebut.

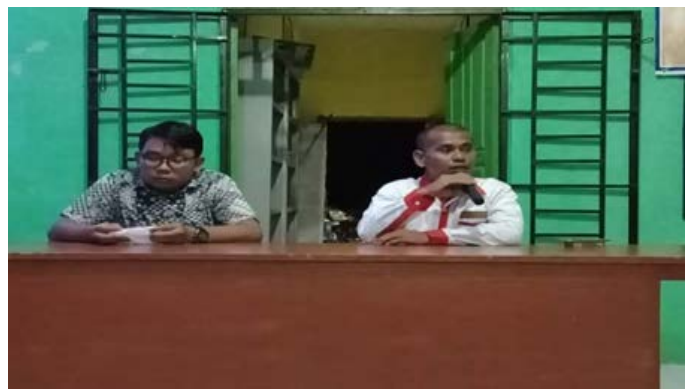

Gambar 1. Kegiatan Pembukaan PKPM Memperkuat Nalar Teologi Islam Moderat Dalam Menyikapi Pandemi Covid-19 di Pimpinan Ranting Pemuda Muhammadiyah Bandar Pulau Pekan.

Di samping itu, juga beliau menyampaikan bahwa peran pemuda sebagai agent of change di tengah pandemi covid-19 saat ini sangat dibutuhkan. Untuk itu sebelum melaksanakan perannya itu pemuda dalam hal ini pemuda Muhammadiyah harus dibekali pemahaman yang mumpuni terkait dengan perannya tersebut. Salahsatu bekal pemahaman yang harus diberikan kepada pemuda
Muhammadiyah adalah sesuai dengan tema yang diangkat oleh tim PKPM FAI UMSU yaitu memperkuat nalar teologi Islam moderat dalam menyikapi pandemi covid-19 di Pimpina Ranting Pemuda Muhammadiyah Bandar Pulau Pekan. Menyikapi pandemi covid-19 ini harus menggunakan nalar yang baik dengan berpedoman pada nilai-nilai ajaran Islam atau Islam moderat itu sendiri.

Setelah kegiatan PKPM tersebut, dibuka oleh ketua Pimpinan Ranting Pemuda Muhammadiyah Bandar Pulau Pekan. Maka, acara selanjutnya adalah pemberian sertifikat penghargaan kepada Pimpinan Ranting sebelum masuk apada acara inti.

Kemudian, kegiatan selanjutnya adalah kegiatan inti pemaparan materi kepada peserta pelatihan, pemateri pertama dalam kegiatan PKPM tersebut yang berindak sebagai narasumber adalah Nurman Ginting, S.Pd.I.,M.Pd.I, beliau merupakan salahsatu staf pengajar pada Fakultas Agama Islam Universitas Muhammadiyah Sumatera utara, dan juga merupakan ketua Tim dalam PKPM tersebut.

Materi yang disampaikan oleh narasumber terkait dengan hakikat dari pada nalar teologi Islam Moderat dalam menyikapi pandemi covid-19. Pada kesempatan tersebut narasumber menyampaikan bahwa peran nalar sangat dibutuhkan untuk merespon segala bentuk perubahan dan perkembangan yang ada di muka bumi ini dengan berpedoman pada nilai-nilai ajara Islam yang moderat. Sehingga dengan demikian segala bentuk perubahan yang terjadi pada saat ini yang disebabkan oleh pandemi covid-19 dapat disikapi dengan berbagai pertimbangan dengan berpedoman pada nilai-nilai ajaran Islam. Pandemi covid19 bukan sesuatu yang harus ditakuti, tetapi harus disikapi, sehingga tidak 
terjadi pelemahan peran dan fungsi kita sebagai manusia yang memiliki ciptaan sempurna dibandingkan dengan makhluk Allah Swt lainnya. Kita harus memaksimalkan peran dan fungsi sebagai manusia dengan mamaksimalkan peran akal dan hati yang telah Allah Swt berikan kepada makhluknya yang bernama manusia itu.
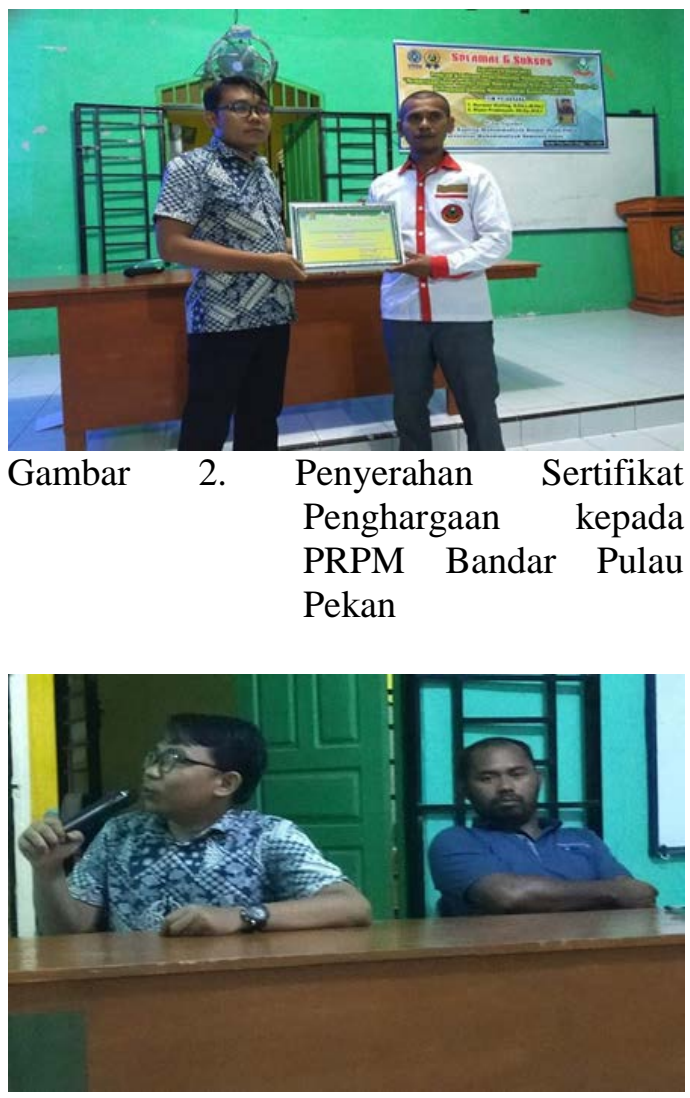

Gambar 3. Penyampaian materi pelatihan oleh Nurman Ginting, S.Pd.I.,M.Pd.I

Setiap kehidupan yang dilakoni manusia di muka bumi saat ini, tidak terlepas dari berbagai permasalahan, musibah, dan berbagai penghalang lainnya. Hal itu, tidaklah menjadikan manusia itu lemah, karena kita dituntut untuk mencari setiap solusi dari setiap permasalahan yang dihadapi. Salahsatu solusi yang harus ditempuh saat ini dalam menghadapi fenomena pandemic covid-19 adalah taat dan patuh serta menjalankan protokoler Kesehatan yang telah ditetapkan pemerintah, baik itu dengan physical distancing, social distancing dan lain sebagainya. Hal itu dilakukan sebagai wujud dari peran nalar yang kita miliki, karena dalam Islam juga dianjurkan untuk menjaga diri Ketika wabah merebah di suatu daerah, Islam menganjurkan kita untuk tetap berada di rumah ketika suatu wabah sedang melanda wilayah tertentu. Hal itu Islam anjurkan agar penyebaran wabah tersebut tidak meluas sehingga akan menyebabkan banyaknya korban yang terjangkit oleh wabah tersebut.

Untuk, itu dalam konteks tersebut pemuda dalam hal ini pemuda yang terhimpun dalam organisasi Pemuda Muhammadiyah memiliki peran yang sangat strategis untuk terlibat secara langsung membangun pemahaman dan kesadaran masyarakat untuk melaksanakan segala bentuk aturan yang telah ditetapkan untuk memustus mata rantai penyebaran pandemi covid-19. Protokoler Kesehatan yang telah ditetapkan pemerintah saat ini dalam mengantisipasi penyebaran pandemi covid-19 merupakan bagian dari nalar Islam moderat itu sendiri. Peran nalar yang kuat sangat dibutuhkan untuk tidak menggap enteng penyebaran pandemi covid-19 tersebut.

Selain itu, juga Pemuda Muhammadiyah yang ada di Pimpinan Ranting Pemuda Muhammadiyah Bandar Pulau Pekan, harus meneguhkan ideologi Gerakan yang terlah dirumuskan Muhammadiyah. Peran teks-teks ideologi Muhammadiyah harus dipahami, karena Gerakan yang pemuda Muhammadiyah itu adalah Gerakan dakwah amar ma'ruf nahi munkar. Salahsatu wujud implementasinya adalah dalam kondisi saat seperti sekaranga ini. Pemuda Muhammadiyah harus memainkan 
peran dan fungsinya sebagai generasi muda yang islami untuk ikut serta berjuang dalam mengatasi penyebaran pandemi covid-19 sesuai dengan tupoksi ortom tersebut.

Kemudian materi selanjutnya berkaitan dengan peran pemuda Muhammadiyah dalam menyikapi pandemi covid-19 melaui 3T; tawazun (seimbang), tawasuth (penengah), tasamuh (toleran). Yang bertindak sebagai narasumber dalam kegiatan tersebut adalah Sahrul Amsari, SE.,Sy.,M.Si, beliau merupakan dosen Fakultas Agama Islam pada Program Studi Perbankan Syariah Universitas Muhammadiyah Sumatera Utara. Beliau juga merupakan wakil ketua di Pimpinan Daerah Pemuda Muhammadiyah Kota Medan. Dalam kesempatan tersebut, beliau menjelaskan kepada peserta pelatihan bahwan peran pemuda Muhammadiyah sebagai generasi Islam yang tangguh harus dapat menyikapi segala bentuk perubahan dan perkembangan yang terjadi saat ini. Salahsatunya adalah keadaan dimana penyebaran pandemi covid-19 yang begitu cepat di Indonesia. pemuda Muhammadiyah harus hadir sebagai pelopor, pelangsung dan penyempurna perjuangan Muhammadiyah. Wujud nyata yang dapat dilakukan pemuda Muhammadiyah dalam kaitannya di tengah mewabahnya pandemi covid-19 saat ini ialah, pemuda Muhammadiyah harus menjadi pelopor untuk terus menyuarakan pentingnya menjalankan protokoler Kesehatan di ruang public di masa pandemi covid-19 saat ini. Hal tersebut merupakan bagian dari pada sikap tawazun (keseimbangan) yang diperankan oleh pemuda Muhammadiyah dalam menyikapi suatu keadaan seperti saat ini. Pemuda Muhammadiyah harus memainkan peran dan fungsinya untuk dapat membantu seluruh elemen masyarakat dan pemerintah untuk tetap tegar dalam menghadapi musibah pandemi covid19. Kita tidak boleh lemah dalam situasi dan kondisi saat ini, kita harus bertindak untuk memutus mata rantai dari pandemi tersebut.

Kemudian, selanjutnya pemuda Muhammadiyah harus menjadi pelangsung dalam memperjuangkan dakwah Muhammadiyah. Salahsatu Tindakan nyata yang dapat dilakukan pemuda Muhammadiyah di tengah pandemi saat ini adalah dengan terus memberikan edukasi bagi masyarakat terkait dengan fenomena pandemi covid-19. Menghimbau masyarakat untuk tidak panik dan khawatir dengan kondisi saat ini. Memberikan pemahaman kepada masyarakat akan pentingnya menjalankan protokoler Kesehatan di ruang public sebagai upaya memutus mata rantai penyebaran pandemi covid-19. Hal tersebut merupakan wujud dari sikap tawasuh (penengah) yang dapat dilakukan oleh pemuda Muhammadiyah di saat pandemi covid-19.

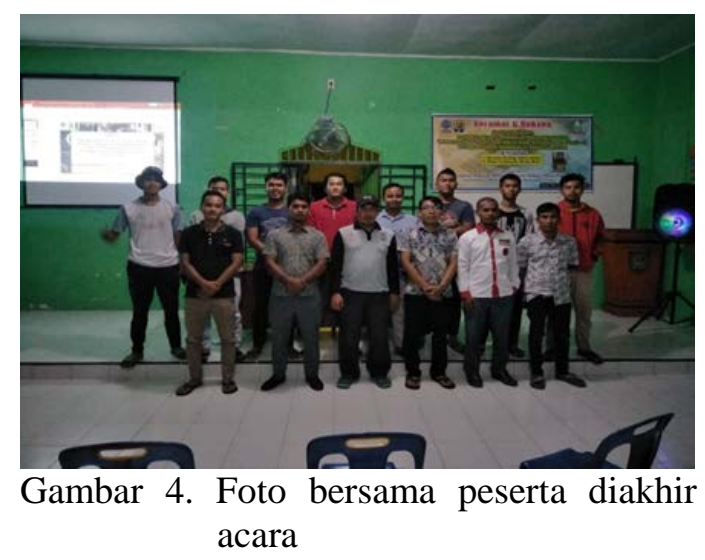

Kemudian, pemuda Muhammadiyah juga harus berperan sebagai penyempurna perjuangan Muhammadiyah. Tindakan nyata yang dapat dilakukan pemuda Muhammadiyah sebagai penyempurnan perjuangan Muhammadiyah di tengah 
Nurman Ginting, dkk. Memperkuat Nalar Teologi Islam Moderat Dalam Menyikapi ...

pandemi covid-19 saat ini ialah dengan secara konsisten melakukan Gerakan keilmuan, Gerakan sosial kemasyarakatan, Gerakan kewirausahaan sebagai tumpuan kegiatan dengan memahami setiap persoalan yang timbul seperti halnya pandemi covid-19. Pemuda Muhammadiyah harus berperan untuk terus mencari solusi yang kreatif dan inovatif dalam menyikapi pandemi covid-19 sehingga terwujudnya ketahanan dalam berbagai aspek (ekonomi, sosial dan kemasyarakatan) dengan tidak melihat identitas RAS. Tindakan seperti itu merupakan wujud dari sikap tasamuh (toleran) yang dapat diwujudkan pemuda Muhammadiyah di tengah pandemi covid-19 saat ini.

Evaluasi yang dilakukan dalam kegiatan pengabdian tersebut, adalah dengan memberikan kesempatan bagi pemuda yang terhimpun di Pimpinan Ranting Pemuda Muhammadiyah Bandar Pulau Pekan, untuk membuat program-program kegiatan yang mencerminkan peran pemuda dalam memutus matai-rantai penyebaran Covid-19. Kegiatan yang telah diprogramkan oleh pemuda yang ada di Pimpina Ranting Pemuda Muhammadiyah Bandar Pulau Pekan tersebut secara berkala mendapat pendampingan dari tim pelaksana Program Kemitraan Pengembangan Muhammadiyah (PKPM) UMSU. Setelah berlangsung PKPM tersebut, setidaknya sudah dua program yang dilaksanakan oleh PRPM Bandar Pulau Pekan sebagai bagian dari ruang lingkup dari materi yang telah disampaikan. Adapun kegiatan yang telah dilaksanakan diantaranya, sosialisasi diantara pemuda mengenai protokoler kesehatan pandemic covid19 sebagai bentuk kesadaran yang harus diimplementasikan setiap individu sebagai upaya preventifisasi penyebaran wabah covid-19.

\section{SIMPULAN}

Program

Kemitraan

Pengembangan Muhammadiyah (PKPM) memperkuat nalar teologi Islam moderat dalam menyikapi pandemi covid-19 yang dilaksanakan di Desa Bandar Pulau Pekan Kabupaten Asahan, dengan mitra Pimpinan Ranting Pemuda Muhammadiyah Bandar Pulau Pekan, merupakan wujud dari adanya relasi antara nilai-nilai ajaran Islam yang bersumber dari AlQur'an dan Sunnah (Teologi) dengan realita saat ini yaitu wabah pandemi covid-19. Pesan Teologi itu membutuhkan penalaran yang baik dengan memosisikan Islam sebagai ajaran yang moderat (washatiyah). Segala bntuk kebijakan yang dilakukan pemerintah saat ini dalam menghadapi wabah covid-19 atau utnuk memutus mata rantai penyebarannya, tidak terlepas dari nilai-nilai ajaran Islam itu sendiri. Peran pemuda disaat kondisi sekarang ini sangat dibutuhkan sebagai agent of change untuk terus memainkan perannya dalam membantu masyarakat terkait pentingnya menjalankan protokoler kesehatan yang telah ditetapkan pemerintah sebagai upaya menghentikan penyebaran covid-19. Pelaksanaan kegiatan ini setidaknya memberikan motivasi dan spirit bagi pemuda yang ada di PRPM Bandar Pulau Pekan.

\section{UCAPAN TERIMA KASIH}

Program

Pengembangan

Kemitraan

(PKPM) atau merupakan skim pengabdian yang dikembangakan oleh LPPM UMSU untuk ikut serta memberikan kontribusi bagi 
persyarikatan Muhammadiyah dalam bentuk pendampingan, pelatihan, sosialisasi dll. Maka, untuk itu tim pelaksana PKPM mengucapkan terima kasih kepada Universitas Muhammadiyah Sumatera Utara yang telah mendanai proposal PKPM ini, setelah sebelumnya dilakukan penilaian terhadap proposal ini, dan dinyatakan lulus untuk di danai.

Tim juga mengucapkan terima kasih kepada mitra kegiatan PKPM yaitu Pimpinan Ranting Pemuda Muhammadiyah Bandar Pulau Pekan dan Bapak Kepala Desa Bandar Pulau Pekan yang telah memberikan izin untuk memakai fasilistas yang ada di Kantor Desa Bandar Pulau Pekan.

\section{DAFTAR PUSTAKA}

Breault, Kevin D. 2009. “New Evidence on Religious Pluralism, Urbanism and Religious

Participation”. Jurnal ASR. No. 6. Vol. 54.

Burhani. Ahmad Najib. 2012. “AlTawassut wal I'tidal: The NU and Moderatism in Indonesian Islam”. Asian Journal of Social Science. Vol. 40. Issue 5-6.

Mulkhan, Abdul Munir. 2010. Jejak Pembaruan Sosial dan Kemanusiaan Kiai Ahmad Dahlan. Jakarta: Kompas.
Nashir, Haedar. 2010. Muhammadiyah Sebagai Gerakan Islam. Yoygyakarta. Suara Muhammadiyah.

Qorib, Muhammad. 2018. "Dakwah Di Tengah Pluralitas Masyarakat.” Jurnal Intiqad. Vol. 10. No.2

Zuhdi, Muhammad Harfin. 2014. "Karakteristik Pemikiran Hukum Islam”. Jurnal Ahkam. Vol. XIV. No. 2.

Syatar, Abdul, Muhammad Majdy Amiruddin, Arif Rahman. 2020. Darurat Moderasi Beragama di Tengah Pandemi Corona Virus Desease 2019 (Covid-19).Jurnal Kuriositas: Media Komunikasi Sosial dan Keagamaan. Vol. 13. No. 1. 